E-46 M ustard 手術16年後の解剖学的右心室不 全に対する二期的 Jatene 手術

東京女子医科大学心研循環器小児外科

新岡俊治, 今井康晴, 星野修一, 石原和明, 澤渡和男, 瀬尾和宏, 寺田正次, 三隅寛恭, 竹内敬昌, 太田 淳, 杉山喜崇, 大野英昭, 久保英三, 平井雅也, 伊橋健治

大血管転位症 ( $d-T G A)$ の心房内血流転換手術は術後 遠隔期《体心室となる解剖学的右心室の機能低下，三 尖弁逆流が問題となる。当教室ではこれらの 5 症例飞 対して肺動脈絞拒術(PAB) による左室トレーニング後に Jatene 手術を施行し全例で良好な結果を得ている。今 回，そのなかの最年長例に対して PAB後 4 週目にWarm Blood Retrograde Cardioplegia 飞ょる心停止下にJatene 手術を施行し良好な結果を得たので供覧する。

【症例】症例は 17 歳, 男児で生後 1 歳 2 力月時に, $d-$ TGA II 型, 大動脈縮窄症 ( C O A ) の診断下飞当院で Mustard 手術および CoA 解除術を一期的に施行された。 術後 15 年頃より体循環心室である解剖学的右室機能不 全, 高度三尖并逆流が出現し, 精查, 手術目的にて入 院した。入院時 CTR 58 \%。 。不全の治療後の心カテー テルイて PCWP 20 mm Hg , LVP 46 /mm Hg RVP 110/EDP $15 m n \mathrm{Hg}$ で, 造影にて TRIII, RVEDV $135 \%$ N , RVEF 44\%, LVEDV $91 \% \mathrm{~N}$, LVEF $62 \%$ を認め大。J atene手術を予定し,左室圧 を等圧をでPABを行い左室トレーニングを行った。3 週 間目に左室後壁厚は $6.1 \mathrm{~mm}$ 上り $11 \mathrm{~mm}$ 严で増加し PABか ら28目に $\mathrm{re}^{-}$-switch 手術となった。

手術洅再胸骨正中切開後, 上行大動脈, 上下大静脈 に直接カニューレを挿入し体外循環を開始した。大動脈 を遮断し大動脈起部より高カリウム $(25 \mathrm{mEq} / \mathrm{L})$ Warm Blood Cardioplegia( 33 C) 亿て心停止とし機能的新 左房 (解剖学的右房) を切開する。心停止後は K 約 8 $\mathrm{mEq} / \mathrm{L}$ の濃度のWarm Blood を持続的に冠灌流する。 心房内バッフルを完全に除去し, EPTFE 膜にて心房中隔 を再構築した。㹡大した三尖弁輪をKay の方法にて形 成した後に冠静脈洞にカニューレを挿入し同様のWarm Bl ood で逆行性灌流を開始する。前方大動脈を起部上 り約20mm の部位で切断。Shaher I 型の左右冠動脈を tear-drop形に切離し, 後方の肺動脈を $\mathrm{PAB}$ の部位で 切断し肺動脈幹に二本の縦切開を加えて冠動脈の移植 を行ら, Lecompteの方法に準じて後方大血管の吻合を 4-0 糸にて連続縫合した。前方血管の冠動脈ボタン欠 損部を二枚の異種心膜で補填拡大後, 大動脈遮断を解 除し加温中に肺動脈の再建を 5-0 PDS 糸による連続縫 合で行い，右房を閉鎖し手術を終了した。大動脈遮断 は146 分であった。患児は術後42日目に元気に退院した。 【京とめ】1.16 年間低圧系心室として機能していた左 心室を28日間のトレーニングで体循環采心室に変換し えた。2. Retrograde Warm Blood Cardioplegia 法に 上る心停止下開心術におらても良好な手術視野が得ら れた。
$E-47\{S, L, L\}$ 你正大血管枟位症、肺動㟲閉錤、

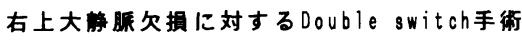

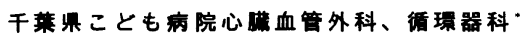
松尾浩三、藤原直、小出昌秋、丹羽公一郎”、 高填裕之。、内柴三佳

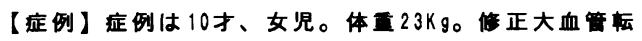

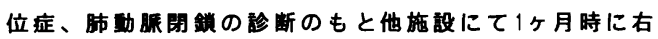
側フレロック短䊀、5才時に左侧フレロック短䊀（变法） を受けている。今回の街前心略カテーテル㛟㚗では肺 野服の発高良好で（PA index=313）、右室及ひ左室拡 張末期容灀はそれそれ104\%、85\% of Normal、収縮率は RV 57.6\%、LV 63.8\%であった。MRI、心エコーの所胃か らもVSDの大きさは十分にありDouble switch法（心房

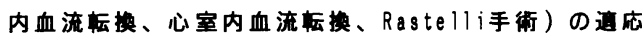
と考えられた。なお本症列は心寈正位であるが右胸心

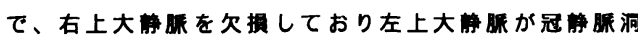
とは別に右原に通流していた。

【手術】朐骨正中切開を行いまず両側のフレロック短 絡を剥誰し、結来系を二重に回す。高端になっている 主肺動㟲及ひ左右の肺動腺を十分に剥してへパリン 投与後、左右肺助㟲を椺断した。主肺助㟲を切崔、右 例にやや切開を拆大して、保存心膜と薄手べロアで予 め作成しておいた直径 $24 \mathrm{~mm}$ の三弁付き心外道管の道位

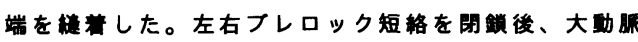

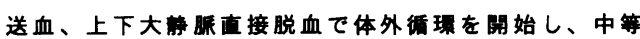
度低体温とした。心尖部を左侧に移動させ右房を切開

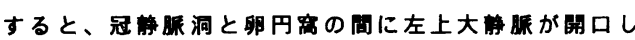

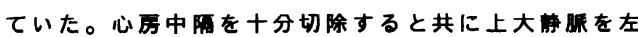

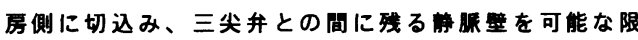
り切除してこのルートを広くとった。フーメラン形の 心房内ハッッフ（保存心膜）を作成し、左側の上大静

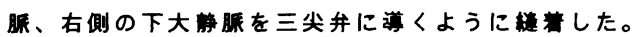
次に右室流出路を切開し、大助睥弁との距注に意し ながら右室筋を切除し、直径 $30 \mathrm{~mm}$ ほとの開口部を作る。 この右室開口部から、大動眼弁とVSDの間にブレジェッ 卜付き4-0及ひ5-0モノフィラメント糸を多数おき、十 分大きな棈円形の保存心䀧パッチを模新、舟形に張り 出して左室流出路が広くなるようにした。ここで新左 房となった右房の切開線を閉鎖し、大助脈遗断を解除 した。体外循理の加温と共に心外薄䈏の近位端を右室

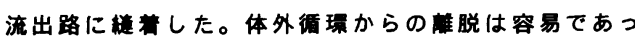
た。

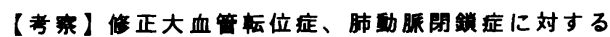
Double switch法は心室容糟、VSD、房室弁なとの条件 が通当であれば、心室大血简閶係正位となり術後の心 機能も良好である。心外道篔は大動脈前方で交差する 形となるが、ステントのない升付き薄管は胸骨の圧迫 に対椨し、容易に胸骨を閉鎖することが出来た。 
E一-48円简状PTFE茾を用いた肺動眼茾置換得 近畿大学医学部心槶外科、

奥秀喬、城谷均、西岡孝純、帛弘志、片山治、 佐贺俊店、若木伸夫、家村順三、北山上士、上田正生、 井上知、松本光史、井上㓮裕

現在、肺助眼弁置換術には一般に生物弁及び機械弁 が用いられているか、前者は酎久性、後者は血栓弁に 関し、また乳児例では弁サイスに関する間通があり、 理想的な代用弁はない。最近、真菌性心内膜炎に対し 自家㱔円简状PTFE弁を用い肺動眼弁罢換を行った。今 回この術式を供筧する。【症例・手術】症例は4思男児。 TFの根治手街後のVSD leak及び肺動眽弁再狭窝に対す るleakの閉鎖とMVOPによる肺動眼再建術施行 8力月後急 激に発熱、IE及び outflow patchのcuspに一致した涨寉

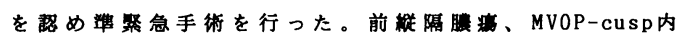
の真菌塊が存在し、自己并は形㙰をとどめていなかっ た。手街は前回用いた outflow patchを切除するまで心 停止下に、肺轩脈再建は心拍䖝下に行った。先ず感染 を受けたRygg-patchを十分切除し、等 $0.2 \mathrm{~mm}$ PTFE

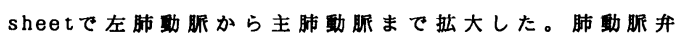
として径 $20 \mathrm{~mm}$ 、長さ $20 \mathrm{~mm}$ 、 $0.2 \mathrm{~mm}$ のPTFE tubeを用 いた。并䋖着は䋖合略部を上に并緑を心室側に向け、

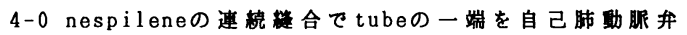
位に䋖着した（図A）。主肺動眼から右室流出路の久損部 分を補填すpatchには厚さ $0.6 \mathrm{~mm}$ のPFE tubeを開いて用 いた。自己肺動眼弁部の一端にpatchの一端を䋖着し、 径 $20 \mathrm{~mm}$ のseizerを弁部に貫いて形成後の弁哈径が 20 m田になるようpatchの他端を肺㲜服弁帢部に䋖着した (図B)。patchの肺助眽僛を心室側へ反転し、tubeの赫

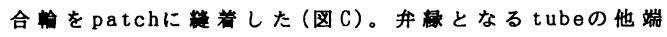

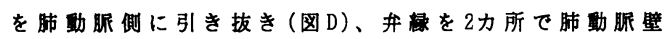
へ、1 1 所でpatchの中央部にvertical mattress継合 で固定して3交連を作成した（因E、F)。最後に右室側 $\mathrm{p}$ a tchを肺動眼側patch及び右室に䋖着した。【結果・考

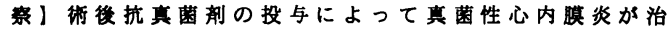

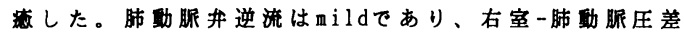
は $3 \mathrm{mmHg}$ 、消足すべき結果を得ることができた。自家 製口简状弁は很中容易に望みうるsizeものが作成でき、

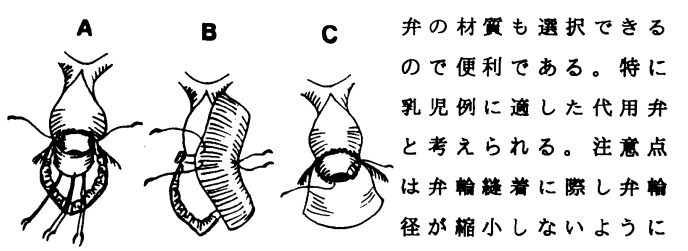

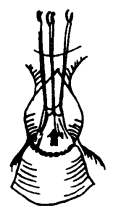

D

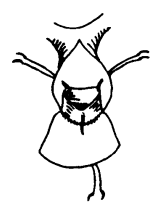

E

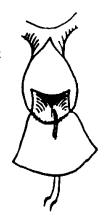

留意すること及び 3 交連 作成時交連间を正確に 円周の $1 / 3$ とし 3 井の接 合を良好に維持するこ とが重要である。
E-49一侧肺動脈欠損を伴う高龄者ファロー四 徵症に対する肺動脈弁位生体弁置換術による根治手術 の一例

札幌医科大学第二外科

高橋典之、安倍十三夫、岡田祐二、田中利明、 小松作藏

ファロ一四徴症に一側肺動脈欠損を合併した症例は まれであり、根治術後に肺動脈高血圧症を誘発し、心 不全状態の增悪を来すことが多くみられる。今回われ われは、左側肺動脈欠損症を伴う 44 荿ファロ一四徵症 に対して、根治手術に際し、生体弁による肺動脈弁再 建を加えることで、術後の肺動脈高血圧症の合併をみ ることなく、良好な結果を得たので、根治手術術式に ついて供覧する。

【症例】症例は 44 藏男性、既往歴として慢性関節り二 ウマチによりステロイド内服治療中である。家族歴で は息子がファロー四徴症にて、当科で根治術を受けて いる。10年前よりファロ一四徵症の彭断を受けるる放 置。平成 4 年 7 月心不全症状により当科外来受㟝。精查 の結果、左側肺動脈久損を伴うファロ一四徵症と診断 される。肺動脈圧は $36 / 7 \mathrm{mmHg}$ 、右室圧は $168 / 4 \mathrm{mmHg}$ 、左 室圧は $180 / 10 \mathrm{mmg}$ 、右室一肺動脈压差は $132 \mathrm{~mm} \mathrm{H}$ であり、 肺動脈造影、肺血流シンチ、MRIなどでは左側肺動脈の 血流を認めなっかった。

【手術】胸骨正中切開、完全体外循㻴下、軽度低体温 下、血液心筋保護法を用い、右室流出路加肺動脈に 加け切開を加えると、左側肺動脈は盲端にて欠損して おり、肺動脈弁は石灰化を呈していた。右室流出路の 筋肉性狭窄部を切除すると、VSDは円錐部全欠損型で、 大動眽台口付右宝照内に露出していた。VSD芥し、在 室からの血流を大動脈に流入すべくダクロン布を用い て、右室流出路の形成を行った。ついで、肺動脈弁を 切除し、Hancock II 25 A により肺動脈弁置換術を施行し た。弁輪は約 $2 / 3$ 周を肺動脈に、残り $1 / 3$ 周をウマ心膜 に繾着し右室流出路の再建拡大術を施行した。術後経 過は順調であり、術後 1 日目のSwan-Ganzによる圧測定 では肺動脈圧は $20 \mathrm{~mm} \mathrm{H}$ 、右室一肺動脈圧差は約 $30 \mathrm{mmHg}$ であった。

【考察】1992年8月末まで、教室におけるファロ一四徵 症根治手術症例は 450 例を数えるが、一側肺動脈欠損症 を伴う症例は 2 例 $(0.4 \%)$ である。欠損側は左側が圧倒 的に多いようである。これに根治手術を施行した場合、 肺血流量の增加と、先天的肺動脈低形成、多血症に伴 う末梢血管の閉塞などにより、術後肺動脈高血圧症を 合併するものが多いとされている。特に高秢者では、 側副血行路が発達し、左房灌流血が多く術後の肺高血 圧予防之、右室流出路狭窄の十分な解除には、生体弁 使用によるパッチ拡大術が有用であった。 
E-50 成人型左冠動脈肺動脈起始症に対する竹 内法一我々の工夫を中心に一

群馬大学第二外科

大滝章男, 佐藤泰史, 石川 進, 吉田一郎, 大谷嘉己, 坂田一宏, 高橋 徹, 市川秀昭, 相崎雅弘, 森下靖雄

左冠動脈肺動脈起始症 (Bland-White-Garland 症候 群）の成人例には，冠動脈バイパス術が好んで用いら れているが, グラフトの長期開存に問題がある. 今回 我々は，本症の成人例に対し，小児例での報告が多い 竹内法（肺動脈内トンネル法）を用いて良好な結果を 得ることができた，竹内法において問題になる肺動脈 狭窄などに対する工夫を中心にビデオで供覧する.

【症例】31歳女性. 17歳頃より時々前胸部痛, 動悸が 出現し, 胸骨左縁第 3 肋間に $3 / 6$ 度の連続性雑音を聴 取した. 標準12誘導では $\mathrm{V}_{2}, \mathrm{~V}_{3}$ にST-T変化色, 荷 心筋シンチで前壁のpersistent defectを認めた. 右冠 動脈造影のrate phaseで, 左冠動脈に続いて肺動脈が 造影され, 成人型左冠動脈肺動脈起始症之診断した.

【手術】左冠動脈は主肺動脈の左背側から起始してお り, direct implantation を行うには距離が遠すぎる ため, 竹内法による血行再建を選択した. 手術は中等 度低体温, 体外循環下に行われ, 大動脈遮断中の心筋 保護として, 大動脈基部からのblood cardioplegiaに topical coolingを併用した. 肺動脈を右室流出路に近 いところで横切開し, 肺動脈内の左冠動脈入口部の位 置を確認し, 肺動脈前壁によるflapの長さ及び幅を決 定した。まず大動脈壁とflap間に直径5.5mmのA-Pwindowを作製し，肺動脈前壁で作った $13 \times 25 \mathrm{~mm}$ の $1 \mathrm{ap}$ を 肺動脈後壁に落とし込んで4-0 ネスピレン系で縫合し， 大冠動脈へ動脈血を誘道する為のトンネルを作製した. この際、flapを可及的に短くするために，A-P window を左冠動脈入口部にできるだけ近づけることが理想だ が，過度に背側へ回り込むとA-P windowの作製が難し くなる. 又, flapの幅を多く取るほど, 左冠動脈への 血流が豊富となるが, 逆にトンネルが太くなり過ぎて 肺動脈狭窄をきたす恐れが出てくる．そのためには欠 損となった肺動脈前壁に大きめのパッチを当てること が必要で, 我々は $45 \times 35 \mathrm{~mm}$ のマ心膜パッチを用いて 肺動脈狭窄を回避し得た。一方, flapによる肺動脈内 トンネル作製後は, 大動脈遮断を解除することが大切 で, それによりトンネルでのleakageを確認でき, さら には肺動脈欠損部に当てるパッチの大きさも選択し易 くなる.

術後は順調に経過し, 心エコーで軽度の肺動脈内圧 較差を認めたが心不全徴候はなく, 左冠動脈への血流 もよく保持されていた。

【結語】稀な成人型左冠動脈肺動脈起始症に対して, 小児例での報告が多い竹内法を応用し, 良好な結果を 得たので，本術式に対し我々が行っている工夫を中心 に報告する.
E-51 解離性弓部大動脈榴に対するIntralumi nal Grafting Method $の$ 経験

東京女子医科大学第一外科

板岡俊成, 村杉雅秀, 足立 孝, 小山邦広, 小野完二, 小原徹也, 瀬戸 拓, 田原士朗, 大貫恭正, 横山正義, 新田澄郎

【目的】主要分岐再建を要する解離性胸部大動脈瘤は, その手術侵襲と成績をめぐり手術方法・適応などな括 議論が多い分野である。今回, 腎機能不全・高齡の手 術危険因子を持つ $\mathrm{S}$ tan ford $\mathrm{A}$ 型解﨎性胸部大動脈瘤 飞対し手術侵襲を少なくする目的とて 3 分枝付き intraluminal graft を使用した弓部大動脈全置換術 を経験したのでその手技・工夫を供覧する。

【症例】症例は76歳, 女性で入院時検査で高血圧症・高 脂血症・腎機能不全 $(\mathrm{CCr}: 65 \mathrm{~mL} / \mathrm{min})$ 拈よび心係数低 下 $\left(2.1 \mathrm{~L} / \mathrm{mi} \mathrm{n} / \mathrm{m}^{2}\right)$ を認めた。胸部レ線像ではこの 2 年 間で上綎隔の扗大を見, また, 胸部 CT・MRI 検査で は上行大動脈から弓部大動脈末梢までの解離性大動脈 瘤と診断された。また，血管造影では主要 3 分枝真腔 より分岐し，上行大動脈基部は偽腔が盲端となってい た。以上のよう飞多くの手術危険因子を伴った慢性胸 部解離性大動脈瘤症例であるが, 最近払大傾向飞ある ため弓部大動脈盾換術の適応と考えた。

【手術方法】当症例は大動脈弁閉鎖不全の伴わない慢 性A型解離例でリング付きグラフト挿入のために充分な る真腔径を認めていたため, 術前飞主要 3 枝血管内径 拉よび下行大動脈内径を計測し弓部大動脈内飞挿入す る 3 分枝 ( $10 \mathrm{~mm}$ 径 1 本, $8 \mathrm{~mm}$ 径 2 本) を有したリング付 き人工血管 ( $22 m$ リング径, USCI) を作成した。全 身麻酔下胸骨正中切開飞て迷走神経・反回神経を温存し 解離していない左鎖骨下動脈遠位部括よび主要 3 分枝 そテーピングを行い, 左大腿動脈送血・右房脱血の体外 循環で脱血温 25 度になったところで右大腿動脈より插 入したballoon catheterとて下行大動脈閉塞すると同 時飞右腕頭動脈・左総頸動脈より分離体外徝環を開始 した。3 分枝遮断後弓部大動脈切開し cardioplegia の後, 作成したリング付グラフト下行大動脈・上行大動 脈に挿入し固定した。この時血管解離部 $8 \mathrm{~cm}$ 以上のた め 20 mm径人工血管でリング間で延長を要した。下行大 動脈遮断解除し冠灌流を得たところで、人工血管 3 分 枝を予定主要 3 分枝内に插入し分岐中权部で封入する ように吻合し脑灌流を得ている。弓部人工血管は大動 脈解離壁で被覆し手術を終了した。大動脈遮断時間 47 分, 人工心肺時間 197 分, 術中出血量 $1020 \mathrm{~m} \mathrm{Lで}$ 術後一時脳血管障害合併したが術後 1 力月血管造影で 偽腔閉塞し術後 3 力月現在外来通院で経過良好である。 【結語】高龄者弓部解離性大動脈瘤飞対し 3 分枝付き リング付きグラフトを使用した graft inlusion technique は, 手術侵襲軽减の面より有効であった。 
E-52分離体外循環と逆行性腷灌流を併用した 慢性 $\mathrm{A}$ 型解離上行弓部下行置換術 市立静岡病院心腿血管外科

島本光臣，山崎文郎，藤田章二，中村隆之，吉村誉史， 上野孝男, 箖崎 拓, 秋山文弥

$\mathrm{A}$ 型解離慢性期症例の手術適応は大動脈弁閉鎖不 全と冠動脈口や弓部分枝狭窄を別にすれば瘤最大径が $60 \mathrm{~mm}$ 超える症例としているが,経年と共に弓部分枝， 下行大動脈の動脈硬化や石灰化のため大動脈遮断が問 題となる症例が多い.一方,循環停止には時間制約に不 安があり,分離体外循環と逆行性脳灌流を併用し弓部分 枝と下行大動脈末梢側を遮断することなく,また心停止 時間と体循環停止時間を減少させ上行弓部下行置換を 行った.

【症例】65 才。女性. $164 \mathrm{~cm} .64 \mathrm{~kg}$.

【現病歴】50才時,解離性胸部大動脈瘤にて 1 力月 入院後降圧片投与されていた.62才時瘤拡大にもかか

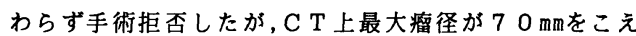
たため手術承諾となった。

【術前検查】 CCre : $28 \mathrm{ml} / \mathrm{min}$. 腹部大動脈瘤最大 径：40 mm. C A G : \# $1370 \%$ 狭窄

【手術】'91.7.15. 正中切開後 2 本脱血,左股動脈 (18F) と腕頭動脈 ( $3.8 \mathrm{~mm}$ ) の 2 本送血（流量 $3.4 \mathrm{~L} / \mathrm{min}$ ), 下に泠却と人工心肺内血液透析を開始する。one lung intubationとし第 4 肋間開胸のdoor openにて下行大動 脈剥離、直腸温 $21^{\circ} \mathrm{C}$ にて左鎖骨下動脈末梢 $5 \mathrm{~cm}$ の下 行大動脈を遮断、股動脈送血停止（腕頭動脈送血 $1 \mathrm{~L}$ $/ \mathrm{min}$ ) とし遮断部末梢 $10 \mathrm{~cm}$ 部で人工血管 (Gelseal $22 \mathrm{~mm}$ ) 末梢側吻合 (所用時間 14 分) を行う。この間 冠動脈と弓部分枝の灌流は行われている.人工血管遮 断し股動脈送血 $(2 \mathrm{~L} / \mathrm{min})$ 開始,腕頭動脈送血停止, 上 行弓部大動脈切開, tapingした S V C より逆行性脳灌流 (静圧 $15 \mathrm{~m} \mathrm{~m} \mathrm{H} \mathrm{g}, 500 \mathrm{~m} 1 / \mathrm{m} \mathrm{i} \mathrm{n}$ ) 開始する. これより心停止時間となる.解離腔内血栓摘出, 弓部 3 分枝をen block人工血管側壁と吻合 (所用時間 30 分) 空気抜き後逆行性脱灌流停止,股動脈送血と加温を開始 する.上行大動脈解離腔中枢は大動脈弁交連部付近，内 膜はそれより $1 \mathrm{~cm}$ 末梢まで残存しており,これをプレジ エット付きU字程合で閉鎖した後 $26 \mathrm{~mm} \mathrm{Gelseal}$ 連続 䋖合にて中枢側吻合する. $22 \mathrm{~mm}$ と $26 \mathrm{~mm}$ の人工血管吻合後 瘤壁にてwrappingする。

【結果と考察】手術時間 8 時間, 人工心肺時間 3 時間 15 分,心停止時間 1 時間 26 分,出血量 $588 \mathrm{~g}$, 輸血 量 $3000 \mathrm{ml}, 7$ 時間後覚醒し䑈障害や腎不全の発生は 認めず,社会生活に復帰している.檤分離体外循環と比 較し弓部分枝遮断のない点で, 循環停止とは体循環停止 の減少と弓部分枝吻合時間に余裕を与える点で利点を 持つ方法と考える。
$E-53$ 逆行性持続脳灌流による遠位弓部大動脈 瘤に対する大動脈弓部全置換術

大垣市民病院胸部外科

村瀬允也、前田正信、寺西克仁、櫻井一、西澤孝夫

【目的】弓部大動脈遠位側に見られる大動脈瘤の手時 に、中枢側吻合がどの部位において施行可能か、術前 に決定することは困難なことが多く、左開胸では弓部 大動脈の硬化性病変のため、中枢側吻合が困難なこと も多い。このような症例に、胸骨縦切開、循環停止、 逆行性持続脳灌流下に弓部全置換を行って良好な結果 を得た症例を経験したので、手術手技を供覧する。

【症例】70歳、男。左前胸部痛を主訴とし、大動脈弓 部の拡大を指摘されて来院した。右半身の知覚障害と 言語障害を伴う脳虚血発作3回の既往があった。CT, MRI，血管造影で、多量の血栓を有し、弓部大動脈に も硬化性病変が合併する可能性が強い遠位弓部大動脈 瘤と診断した。

【手術】胸骨縦切開を左鎖骨上穸に延長した。大動脈 を左肺門近くまで剥離し、末梢吻合部が吻合可能なこ とを確認した。上行大動脈にも非常に固く触れる部分 があり、硬化性病変が広範囲であると考えられた。大 動脈遮断による粥種の離脱、塞栓の可能性が強く考え られたため、大動脈遮断を行わない方針とした。上行 大動脈送血、上下大静脈脱血により体外循環を開始し、

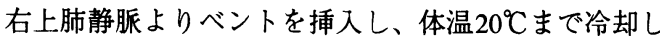
た。体外循環を停止し心房切開、逆行性心筋保護を行 い動脈瘤を切開した。逆行性持続脳灌流を行いつつ動 脈瘤内の血栓を除去し、上行大動脈の方向に内膜面を 検索すると、腕頭動脈基部まで高度の硬化性病変で、 弓部全置換が必要と考えられた。末梢側は外周にフェ

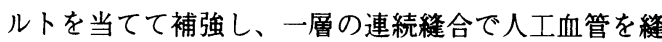
合した。左総䅡動脈、腕頭動脈を別々に人工血管に繾 合した。人工血管に縫合しておいた側枝から送血を行 うこととし、空気抜きを行って人工血管を遮断して体 外循環を再開した。人工血管と大動脈中枢側を外周に フェルトを当てて一層の連続縫合で吻合した。大動脈 遮断を解除し、自然に心拍の再開が得られた。人工血 管側枝と左鎖骨下動脈の吻合を行った。逆行性持続脳 灌流時間 83 分、心筋虚血時間 128 分、人工心肺時間 270 分であった。

術後の覚醒は問題なく、術後経過は良好に回復し、 脳障害もなかった。

【結論】遠位弓部大動脈瘤の手術は左開胸で行われる ことも多いが、弓部分枝の遮断を要することも多く、 脳分離体外循環を必要とすることもある。動脈硬化性 病変が中枢側吻合部に強く見られ、吻合困難な症例も ある。胸骨縦切開による方法は、逆行性持続脳灌流を 併用することにより、これらの症例に対処可能で有用 な方法である。 
$E-54$ 逆行性脳灌流・超低体温循環停止を補助 手段とした遠位弓部大動脈瘝手術

天理よろづ相談所病院 心臟血管外科

上田裕一 三木成仁 大北 裕 田畑隆文 酒井哲郎 松山克彦

大動脈弓に波及した大動脈溜の手術に，われわれは， 1987 年以来弓部之その分枝を全く遮断しない超低体 温循環停止 (DHCA) と持続的逆行性脳灌流法(CRCP) を採用している。大動脈弓遮断での手術も可能とされ る遠位弓部大動脈瘤手術に際しても，壁在血栓による 塞栓の予防を意図して, 積極的にこの補助手段を導入 している。特に遠位弓部大動脈瘤手術における術式上 の工夫につきビデオを供覧する。

【症例】76才男性。以前から遠位弓部大動脈瘤を指摘 され, 他院で経過観察中であったが, 1992年 4 月嗄声 が出現, 瘤が拡大してきたため, 当院を紹介された。

【術式】胸骨正中切開を行い，上行および弓部を超音 波検査し，健常な上行大動脈に送血管を挿入，上，下 大静脈脱血で体外循環を開始した。中心泠却の間に，

弓部前面を剥離した。なお，この間に左大腿動脈に送 血管を挿入したが，遮断したままとしておいた。VF となった㭙点で，大動脈基部で遮断，心箭保護夜を注

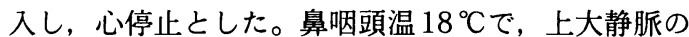
脱血管を遮断, 内頸静脈圧を高値に保って, 送血管お よび下大静脈の脱血管も遮断して DHCA とした。弓 部分枝は遮断をせずに大動脈弓を縦切開し，壁在血栓 を徹底的に摘除した。動脈硬化病変は弓部全体に波及 しており，上行大動脈まで置換することにした。末梢 側, 弓部分枝起始部, 中枢側(健常な上行大動脈)の順 に吻合したが，この間は経上大静脈にCRCPを行い脳 庇護をはかった。CRCP終了時にはじめて大腿動脈か らの送血で下行大動脈および人工血管内を満たした。 人工血管の縫合を完了して，復温を開始したが，再び 上行大動脈送血に切り替えた。体外循環を離脱, 閉胸 し, 手術を終了した。

【結果】最低体温は $16.9^{\circ} \mathrm{C}$, 循環停止は 78 分, 体外循 環時間は 192 分，手術時間は 330 分であった。輸血は 術後に 3 単位用いたのみであった。覚醒は術後 9 時間, 術翌朝には抜管でき, 術後 2 日には一般病棟に転出,

経過は順調で術後 22 日に退院した。

【考案】遠位弓部大動脈手術では，大動脈や弓部分枝 の遮断による壁在血栓の脱落・散布，あるいは灌流再 開時の塞栓の危険性が問題となるが, 本補助手段は遮 断が不要で, 操作中も弓部分枝内への血栓・粥腫の脱 落が防止できる大きな特長がある。遠位弓部であって も硬化病変は弓部全体に波及していることが多く，全 体を観察して，適切な吻合部を選択することも肝要で ある。さらに遠位弓部大動脈瘤内の壁在鄰腫が大腿動 脈送血による散布されるのを危惧し，上行大動脈基部 を送血部位として選択し良好な結果を得た。
E一55全身逆行性灌流法を用いた近位下行大動 脈瘤の手術

名古屋大学胸部外科、四日市市民病院心臟外科* 松浦昭雄、保浦賢三、柵木隆志、市原利彦、伊藤敏明 宮原健、阿部稳雄、岡本浩*

胸部下行大動脈瘤の手術は、右大腿動脈からのF-F ハイパスあるいは左房一大腿動脈シャントの補助手段を 用いて、左側開胸にて瘤の上下で大動脈を遮断して行 う方法が一般的である。しかしこれらの術式では、瘤 が弓部大動脈近傍から始まり、左総頸動脈と左鎖骨下 動脈の間あるいは左銷骨下動脈直下で大動脈遮断せさ るを得ない場合、遮断部位のアテロームや壁在血栓が 挫隇して浮遊散布されて起こる術中脳合併症が問題と なる。我々はこの clampinjuryを回避する為に、全 身逆行性灌流法を応用して、大動脈非遮断にて胸部下 行大動脈癌切除人工血管置換術を施行し、良好な結果 を得た。今回この新しい補助手段による手術をビデオ にて供覧する。

【症例】42歳男性。胸部レ線撮影で上繸隔院影の拡大 が発見され、精查の結果、左鎖骨下動脈起始部近傍か ら始まる紡錘状動脈瘤が確認され、手術となった。

【手術術式およひ結果】左右分離換気下に胸骨正中切 開を行い、左側胸膜を切開して癌に到達した。健常部 上行大動脈に送血管、上下大静脈に脱血管を挿入して、 通常の体外循瓄を開始し、全身冷却した。心室細動と なった所で右上肺静脈より左室へントチューブを㨂入 して滅圧し、直腸温が 20 度 c まで低下した時点で、脳 保護剂(マニトール、フェニトイン)を投与し、上大 静脈の脱血管を選択的に内䫫静脈に挿入た後循環停止 とした。動脈㾞を繸切開して隇圧し、冠静脈洞から逆 行性冠灌流にて心筇保護を行いつつ、上下大静脈より 脳およひ腹部喴器へ酸素化血を逆行性に送血し、それ それ静脈圧が $25 \mathrm{~mm}$ mを超えないよう流量を調節した。 弓部分枝およひ下行大動脈からの還流血を吸引しつつ

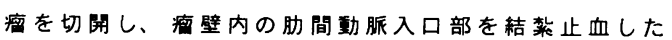
後、中枢側断端に $20 \mathrm{~mm}$ ゼラチン処理人工血管を端々吻 合した。大動脈弓部およひ人工血管内の空気を抜きつ つ人工血管を遮断し、上下大静脈からの送血を停止し、 上行大動脈の送血管から順行性送血を再開して通常の 体外循㯰に復㛿した。さらにオクルーショョンパルーン で下行大動脈を閏塞し右大腿動脈から送血しつつ、人 工血管の末梢側断端を下行大動脈に吻合して手術を終 了した。体外派環時間 215 分、逆行性脳体循塄時間 41 分、 上行大静脈送血流量平均 $160 \mathrm{ml} / \mathrm{min}$ 、下行大静脈送血流

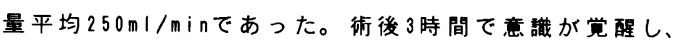
経過は順調であった。

【考察】本法は、大動脈の遮断がないので吻合が容易 であり、また大動脈の障謇によって起こる脳合併症を 防止できる利点があり有用な手術法である。 
E一56 Bentall 手術後の DeBakey III b 型解離 に対する胸部下行及び腹部大動脈の全下行大動脈 完全置換手術

慶應義塾大学外科

四津篒苹，井関治和，小野口勝久，志水秀行， 伊藤 努, 加戸 靖, 三岡 博, 川田光三, 川田志明

解離性大動脈溜に対して, 救命的手術が選択さ れる一方，上り根治性を求めた拡大血行再建手術 が探究されている。我々は, Marfan 症候群を伴う II +II b 型解離に対して, Bentall 或は Cabrol 手術 後に 2 期的に胸部下行, 腹部大動脈に及ぶ全下行 大動脈の再建手術を 2 例に行なった。第 1 例は 26 歳男性で Cabrol 手術後, 第 2 例は 34 歳女性で Bentall 手術後である。いずれも術後対麻痺もなく 極めて順調に経過した。以下に本手術における種 々の丁夫を述べる。

1. 補助手段下に順行性或は逆行性灌流を組み 合わせ末梢側から再建を開始し，大動脈の段階的 遮断法を第一選択とし春餚と腹部蔵器を含む臟器 阻血時間を最少限としたことを強調する。

2. 主要肋間動脈は瘤内から再建した。

3. 腹部主要分枝の再建はDeBakey 法により枝 付き人工血管に一本づつ端々吻合で行なった。

4. 補助手段として第 1 例はシャントチューブ法 を，第2例は遠心ポンプによる左心バイパス法を 選択した。いずれも $0.3 \mathrm{mg} / \mathrm{kg}$ の少量のへパリンを 加え, ACT 150 秒前后で十分であった。教室の実 験から左心機能低下に対しては後者（左心バイパ ス）が有効なので左心機能低下を認めた第 2 例に は本法を採用した。

5. 中枢側人工血管の端々吻合に際し，宿主血 管脆弱性に対する化学的吻合部補強法として,グ ルタール液による「術中なめし処理吻合法」を行 なった。

6.いずれも術中エコーによってェントリーの 検索，確認を行なった。

7.術中SEPモニタリングを行なった。

以上につき，第 1 例はシェーマにつき，第 2 例 は手術の実際を手順を追って供覧する。

【症例】 34 歳, 女性。Marfan 症候群

〔経過]急性 II 型, 慢性 IIb 型の診断て緊急Bentall 手術を施行。退院 4 ケ月で残存四 bの拡大による腹 部症状を認めた。向 b 解離は胸部下行から腹部大動 脈に至る全下行大動脈に及んでおり，最大径は腎 門部位で $7 \mathrm{~cm}$ であった。心ェコー所見で Bentall 手術部位は良好であるが，左心機能低下を認めた (EF 48\%)。

以上，供覧する症例をもとに，本術式の利点や種々 の工夫について, 我々の経験を通して検討したい。

\section{$E-57$ 全腹部大動脈置換を伴なう胸腹部大動脈瘤} 手術

琉球大学第 2 外科

古謝景春, 国吉幸男, 伊波 潔, 赤崎 満, 宮城和史, 久貝忠男，下地光好，大田 治，佐久田斉, 鎌田義彦、 川畑 勉，大嶺 靖, 草場 昭

広範型胸腹部大動脈瘤は腹部主要分枝之, 脊髄動脈 の再建を要することが多く，その適応と手術成績をめ ぐってなお論議が多い。

我々は最近本症に対し，積極的に瘤置換を行ない良 好な成績を得ているが、今回は全腹部大動置換を伴な う広範型胸腹部大動脈瘤手術の要点を映画にて供覧する。 症例は57才男性で，高血圧を有し，腹部大動脈瘤の 診断で入院となった。術前検査にて下行胸部から右総 腸骨動脈に及ぶ最大径 $7 \mathrm{~cm}$ の胸腹部大動脈瘤と診断し, 胸部下行から腹部大動脈分岐部以下までの瘤置換を行 なった。

手術は左第 7 肋間を含む spi ral opening 下に後腹膜 アプローチにて, 胸部下行大動脈から両側腸骨動脈ま での瘤全体を直視下においた。同時に大動脈用グラフ 卜に左右腎動脈用の側枝付グラフトを作成した。術中 の大動脈遮断の補助手段として F - F バイパスを使用

し，また同時に SEP モニターを行なった。 瘤置換は, 各所属蔵器保護の観点から, 分節的遮断 下に，以下の如く中枢側より順次再建を行なった。

1) 中枢側胸部下行大動脈一大動脈グラフト端々吻合。

2) Adamkiewicz 動脈（ $\left.L_{1}\right)$ 再建（ボタン法）

3 ）腹腔動脈, 上腸間膜動脈同時再建。

4 ）両側腎動脈再建（側枝との吻合）

5 ) $\mathrm{L}_{3}, \mathrm{~L}_{4}$ 腰動脈再建（ボタン法）

6）Y Y゙ラフトによる遠位腹部大動脈瘤置換（左内腸 骨動脈温存)

7 ）中枢側大動脈グラフトーY グラフト端々吻合。 以上の装作に要した大動脈遮断時間は 159 分であり,

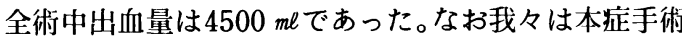
において特に腎動脈の灌流を行なっていないが，供覧 した症例の腎血流遮断時間は右が15分，左が25分であ つた。術後経過は良好で，対麻痺，腎不全等の合併症 はなく, 術後 4 週目の造影で, 腹部主要 4 分枝及び腰 動脈の良好な再建を確認して軽快退院した。

以上全腹部大動脈置換を伴なう胸腹部大動脈瘤手術 を供覧するが，本症手術の要点として対麻㾝及び腎不 全対策が挙げられる。我々は対麻痺予防策として太い 口径の脊咀動脈は可急的多く再建する方針とし，本症 例でも 3 本の腰動脈の再建を行なった。また腎動脈再 建において側枝付グラフトの使用は，腎血流遮断時間 の短縮化の観点から有用な方法と考えている。 
$E-58$ 高度の肺症着を合併する遠位弓部、胸部下 行大動脈瘤と腹部大動脈瘰症例に対する二期的手術 浜松労災病院心䂸血管外科

楠原健同、岩倉篤、坂田晃一

[はじめに]胸部下行大動脈瘤の手術において、肺の 潓着は、超低体温、体外循罢などで血液凝固機転に破 糘を来した場合、剥離面の出血、压排による肺出血な どのため致命的となり得る。われわれは左上肺葉の著 しい線䊒化と㾇着を合併した遠位弓部、胸部下行大動 脈溜の手術を経験したので、ビデオで供筧する。

[症例] 68才男性。高血压、糖尿病なし。血液、生化 学検查などとくに異常は認めなかった。血管造影、C $\mathrm{T}$ 検查にて胸部および腹部に大動脈瘤を認めた。胸部 は遠位弓部より下行へ向かって径 $6 、 4 、 6 \mathrm{~cm} の 3$ 個 の寒状瘤か連なる大動脈瘤で、腹部は左堅動脈分枝よ り両棇晹骨動脈に至る径 $6 \mathrm{~cm}$ の大動脈㿔であった。肺 は胸部 X 線、 $\mathrm{C} T$ 検査にて左上肺野の無気肺を認めた。 [腹部大動脈瘤手術] 正中切開にて開腹。腹部大動脈 を督動脈分枝上部にて遮断し、癛を切開。左堅動脈口 をッバ上に残し、冷却生食水を腎動脈口より注入し、 Y 型人工血管中枢側を吻合した。大動脈遮断を人工血 管に移し、人工血管両 $\mathrm{Y}$ 脚を、外、内腸骨動脈分岐部 に吻合した。下腸間膜動脈は不明で再建しなかった。

[胸部大動脈瘤手術] 胸骨正中切開し、大動脈弓部を 露出した後、左第 7 助間開胸にて胸部下行大動脈を露 出した。㿇と肺との瘾着剥離を進めるためさらに第 4 胁間開胸を追加したが、左肺上葉は全体に弾性硬で圧 排することができず、瘤と肺との剥離はしなかった。 上行大動脈、左大腿動脈に送血管を、上、下大静脈に 脱血管を挿入し、上行大動脈送血で体外循懪による冷 却を開始した。心室細動となった時点より心筋保護に よる心停止とした。咽頭温 $18^{\circ} \mathrm{C}$ で循摆停止後、弓部大 動脈を瘦に向加って切開し、同時に上大静脈送血によ る逆行性脳灌流を開始した。動脈壁の㢸状変性が高度 で、弓部第 2 分枝位で弓部を切断し、人工血管を端々 吻合した。人工血管末梢側を罍内に㨂入し、下行大動 脈を痹の所で切開し、人工血管を引出した。人工血管 および下行大動脈を遮断し、分離体外循㻴で、加温を 開始した。左鎖骨下動脈を人工血管に端倒吻合後、人 工血管末梢側吻合を施行した。総体外循環時間 177 分 大動脈遮断心停止時間 69 分、循瑔停止、逆行性脳灌流 時間 27 分、逆行性送血量 $1.5 \mathrm{~L} / \mathrm{min}$ で、また術中自己 血回収装置を用い、術中総輸血量は $3300 \mathrm{~m} 1$ であった。

[考察および結語] 今回、一期的手術では大腿動脈送 血で腹部大動脈瘤内血栓を中枢倒に送る可能性がある、 手術浸隼が大きいという理由で、二期的に行った。胸 部下行大動眽瘤手術術式として、人工血管中枢側吻合 後、㢞全体を開放せず、人工血管を、㢞内を通して末 梢と吻合する方法を用いたが、これは肺上枼の檍着で

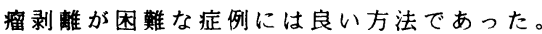

\section{E一-59留血管性高血圧症を合併した異型大動脈綰} 窄症の手術経験

神戸大学第 2 外科

岡田昌義、山下長司郎、吉田正人、太田稔明

腎血管性高血圧症は外科的に改善しうる高血圧症の 1 つであり、教室でも現在までに 34 例に対して手術が実 施され、満足すべき成績がえられている。今回最近経 験した腎血管性高血圧症を合併した異型大動脈縮窄症 に対する手術例をビデオにて供覧する。

症例は 48 歳、男性。主訴は全身倦怠感と上下肢の血 圧較差である。

血圧は $180 \sim 220 / 90 \sim 100 \mathrm{~mm} \mathrm{Hg}$ と高く、近医にて 降圧療法をうけていたが軽快せず、当科に入院し、精 查した。その結果、アンギオ上大動脈炎症候群により 両側堅動脈分岐部の腹部大動脈は石灰化を伴う完全閉 塞、左祭動脈も起始部で閉塞、右堅動脈並びに上腸間 膜動脈と下腸間膜動脈には $75 \%$ の高度の狭窄病変が認 められた。しかし腹部臟器へは側副血行路により血行 障害はみられなかったが、両下肢の API は左側が 0.59、 右側が 0.46 と著明に低下していた。一方、レノグラム では左腎機能はなく、その縦径は $8 \mathrm{~cm}$ と縮小していた。 レニン活性值は左側が $120 \mathrm{ng} / \mathrm{ml} / \mathrm{hr}$ 右側が $51 \mathrm{ng} /$ $\mathrm{ml} / \mathrm{hr}$ といづれも高く左側は右側の 2.4 倍を示した。 上下肢の血圧の較差は歩行後には $100 \mathrm{~m} \mathrm{~m} \mathrm{Hg}$ 前後に上 昇した。以上の所見より、手術を実施した。まず、胸 骨並びに腹部正中切開を行い、上行大動脈之腹部大動 脈末梢側との間にWoven Dacron（径 $14 \mathrm{~mm}$ 、長さ $45 \mathrm{~cm}$ ）にてバイパスを施行した。なおグラフトの走行 は上行大動脈から右室の右側を通し、右横隔膜を通し て肝左葉の下面から胃の後壁を通して本来の腹部大動 脈に走行せしめた。繾合糸は3-0 Nespylene系を用 い、吻合法としては端側に行ったが、吻合口はいつれ も $2 \mathrm{~cm}$ と大きくとった。ついで右腎動脈へ大伏在静脈 を用いて aorto-renal bypassを施行したが、腎動脈 との吻合は 5-0 Nespylene系を用いる端々吻合にて 行い、最後に左腎摘出術を行った。摘出腎の大きさは $8 \times 4 \mathrm{~cm}$ 、重量は $50 \mathrm{~g}$ と萎縮していた。術後血圧は上下 肢とも同等となり高血圧は消失し、十分な尿量もえら れている。さらに術後の造影で血行再建術を実施した 部位の開存が証明された。本症例の手術適応、術式に ついてわれわれの治療方針を詳報する。 
E-60 S J M 弁付グラフトによるBentall 手術 - Carrel patch再建の無輸血手術への工夫術式一 心䑏病七ン夕一棉原病院 心搭血管外科

畑 隆登，難波宏文，津島羲正，手塚光洋，松本三明 村上貴志，濱中莝平，八島正文，谷口 堯

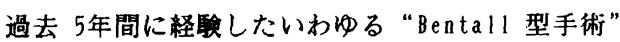
は12例であり，この内 4 例にS J M 弁付グラフトを使 用する機会をえた。術式の工夫により4例中 3例で無 輸血手術が可能であり，手術の質的向上につながった ので，手術手技をビデオにて供臨する.

【症例】Marfan症候群の37歳女性。家族歴でも，45歳 にて母親が，33嵅にて姉が突然死をしている．また43 葴で兄がAVRをうけている。精查の結果, $5.5 \mathrm{~cm}$ の上行大動脈渵と A R II 。を認めた.

【手術】S J M弁付グラフトは, 長さ $10 \mathrm{~cm}$ woven Dacron (porosity $\left(130 \mathrm{~m} 1 / \mathrm{min} / \mathrm{cm}^{2} / \mathrm{mmHg}\right.$ ) $2 S \mathrm{~S} \mathrm{M}$ 弁 を释着したcomposite graft よりなり,人工弁䋖合輪 は double-velour Dacronの sewing cuffを有してい る. Composite graft のサイスを術前の検查により決 定し, Dacron felt ( $5 \mathrm{~mm}$ 幅 $\times 0.5 \mathrm{~mm}$ 厚) を人工弁䉽合 輪に䉽着し、人工弁を保護しながらアルブミンによる preclottingを行った. 本例で使用した composite graft は，25AVG-301 であった. 胸骨正中切開, 大腿 動脈送血，上下大静脈脱血下に中等度低体温体外偱環 を行い, 大動脈遮断後に冠動脈口 $1 \mathrm{~cm}$ 末梢で大動脈を 離断し, 左右冠動脈上り選択的心筋保讙液注入を行っ た. 両冠動脈口を径 $1 \mathrm{c}$ にボタン状にくりぬき, 周囲 粗織を䄪 $1 \mathrm{~cm}$ 别離し释合時の㗨張褑和を考虑した。大 動脈弁輪より $5 \mathrm{~mm}$ 大動脈壁を残して大動脈瘤を切除し た. 3-0 spagetti\&felt付結節綘合糸を用い，大動脈 壁外側より大動脈弁輪に全周性15対の系かけを行い, 前処置した S J M 弁付グラフトを释着した. さらに 4-0 monofilamentに用い, Dacron felt スカートと大 動脈壁を連䊦䉽合して弁輪部の補強を行った，両冠動 脈口の再建は, ドーナツ状の Teflon feltを外側補強 に使用して，4-0 monofilamentによる連続綎合を行つ た.さらにcomposite graft の人工血管 $28 \mathrm{~mm}$ と末梢側 大動脈壁を4-0 monofilamentにて, 密に連続吻合を行 った．また各吻合が終了する事に，心筋保護液による “加圧もれ試駿”を行い，必要により追加吻合を行っ た. 末梢側吻合部補強には, 全周に Teflon feftを被 覆した，充分な空気抜きと可及的可能なまで直接返血 を行い手術を終了した．人工心肺回転時間 194分大動 脈遮断時間 164 分であった。

【結語】S J M 弁付グラフトを用い，Carrel patch再 建による “Bentall 型手術”を行った。本グラフトに も改良すべき点は考えられるが，すぐれた弁付グラフ トであり，術式の工夫により無輸血手術率向上が期待 される。

\section{E-61 CABROL 手術}

一術中出血対策と上行大動脈広範切除を目標とした方法一 福岡大学心臓血管外科

木村道生、助広俊吾、中村正直、芝野竜一、

穴井堅能、岩隈昭夫、山田隆司

【緒言】Cabrol 手術の術中、術後の問題点として、

1) 術中の出血、ことにComposite graft (CG)、中枢 側吻合部からの出血、2) CG の wrapping、更に右房 との短絡作成か、将来人工血管周囲の血腫形成と左右 短絡残存の可能性、3) 残存上行大動脈における瘤、解 離発生の可能性が考えられる。そこで止血を目標に

1）自己心膜片を大動脈弁輪とCG の間に挿入、サンド イッチ法とした。2）CG内の人工弁縫着は 2列の全周 囲巾着縫合をおき、释合輪の緊迫度を増強して針穴か らの出血予防を試みた。3）いわゆるCabrol trickを 省略した。次に、可及的上行大動脈の広範囲切除を目 標として腹部大動脈瘤用遮断鉗子を使用して上行大動 脈末梢側の切断と吻合操作の簡易化を試みた。

【症例】33才女性、労作時呼吸困難を主訴之する。心 胸比 67\%、MRIにて Annuloaortic eclasia と胸部下 行大動脈瘤か認められ、III度の AR とI 度のMRを合 併していた。

【手術】胸骨正中切開、心膜絴切開をすると、直径 $6.8 \mathrm{~cm}$ の $\mathrm{AAE}$ 認めた。上下大静脈脱血、大腿動脈 送血、右上肺静脈より左室ベント挿入、心停止後上行 大動脈瘤を縦切開した。 $8 \mathrm{~mm}$ 径の Gelseal coronary tubeの一端を左冠動脈口に綘着。A 弁切除、 $25 \mathrm{~mm}$ CarboMedics二葉弁をつ $26 \mathrm{~mm}$ Gelseal 人工 血管よりなるCG と、大動脈弁輪との間に自己心膜片 を㨂入して連続綘合にて吻合した。人工弁の縫着は、 2 列の巾着縫合を利用した。右冠動脈口へcoronary tubeの他端を吻合、CG と coronary tubeは相接する 面の角度にあわせて切開線を入れ、側々吻合。上行大 動脈の末梢側は、腕頭動脈起始部に近く腹部大動脈瘤 用遮断鉗子を加け上行大動脈を可及的広く切除、上 下でなく左右に広がった切断面を出した。縫合は、背 側が一直線のため、Felt片を一葉外側に追加したが、 容易に縫合できた。この症例怯、瘤の形状がバルサル バ洞に近々 pear - shaped型と思われたので、open distal anastomosis仗使用しなかった。

【結果】(1)術中の出血量は505gであった。(2)術後 DSA, CT 所見では血腫形成や压迫徵候はなかった。 (3)長期経過をみるべをであるが、術式として今後継続 してよいるのと考えている。 
E-62 大動脈弁置換術後, 大動脈并輪拡大, 上 行大動脈瘤に対するCabrol手術

北海道大野病院心臓血管外科

佐々木昭彦, 岡田祐二, 寺井 浩, 杉木健司, 大野猛三 札幌医大第二外科

数井暉久

大動脈弁置換術後の再手術におけるCabrol手術を供 覧する。症例は61歳, 男性で1987年12月 9 日に大動脈 弁閉鎖不全の診断で $31 \mathrm{~mm} \mathrm{SJM}$ 弁にて大動脈弁置換術施 行した。その時既に大動脈弁輪の拡大をともなってい た。切除した大動脈弁尖は希薄で, myxoid変性をとも なっていたが，大動脈には囊胞状中膜壊死の所見はな かった。術後外来で経過観察していたが，1992年 4 月 12日左片麻瘏出現, CT検查にて右中大脳動脈領域の梗 塞と診断され, 同時に上行大動脈瘤を指摘された。 $\mathrm{t}-$ PA療法にて麻疸は消失した。当院入院後血管造影に て, 人工弁直上より上行大動脈が最大径 $7.5 \mathrm{~cm}$ に拡大 していた。人工弁機能は正常であった。1992年 7 月 16 日, 胸骨再正中切開, 胸骨裏面, 右室前面, 上行大動 脈, 右房側を円刃ナイフと電気メスにて癋着䟝離後, 上行大動脈送血, 右房脱血の部分体外循環を開始した。 中等度低体温法で大動脈遮断後瘤を縦切開し, 直接左 右の冠動脈口から血液心筋保護液を注入した。右冠動 脈口は上方に変位していた。人工弁の開閉状態を見る と, 二葉弁の辺縁に大動脈側と左室側に薄くパンヌス 形成を認め, 八サミにて切除した。 $8 \mathrm{~mm}$ アルブミン熱 処理人工血管を 4-0 プロレン系の連続縫合にて左冠動 脈口に吻合した。人工血管より血液心筋保護液を注入 し, 出血部位に数針追加縫合を加えた。次いで㑇性内 膜のはった人工弁の縫着輪に，スパゲッティつき2-0 テフデック系を外側から内側に針を刺入した後, $30 \mathrm{~mm}$ アルブミン熱処理人工血管の内側から外側に針を刺入 しマットレス縫合にて人工血管を人工弁に縫着した。 $8 \mathrm{~m} m$ 人工血管の一方を右側に回して, 4-0プロレン糸 の連続縫合にて右冠動脈口に吻合した。30mmの人工血管 と $8 \mathrm{~mm}$ の人工血管に側孔をあけ，4-0プロレン糸の連 続縫合にて人工血管同志を側々吻合した。24mm Foley バルーンカテーテルを $30 \mathrm{~mm}$ の人工血管に挿入し，血液 心筋保護液を注入し, 冠動脈口吻合部, 人工血管吻合 部に出血のないととを確認した。最後に人工血管と上 行大動脈の末梢側吻合を, ともに外側にテフロンフェ ルトで補強し 3-0プロレン系の連続縫合にて行った。 吻合終了直前に人工血管内より空気を除去しながら大 動脈の遮断を解除した。上行大動脈より air vent を行 い, 除細動器にて心拍再開した。人工心肺の離脱は容 易で，麻酔の党醒もよく翌日抜管した。術後 1 力月目 の血管造影では, 両側の冠動脈口は良好に開存し, 人 工血管吻合部にも異常を認めなかった。
E一63左冠動脈主幹部単独病変に対するパッチ 拡大術一無輸血手術が可能であった 1 症例一 社会保険紀南綜合病院心臟血管外科

平中俊行, 阪越信雄, 矢倉明彦, 前田 晃

左冠動脈主幹部 (LMCA) 病変に対するAngioplasty は，1983年Hitchcockらが良好な成績を報告して以来 みなおされ，本邦においても報告例がみられるように なっている。

今回われわれは，LMCA単独病変に対するパッチ拡大術 を, 術前眝血を行うことなく無輸血で施行しえたので, その症例の手術手技を供覧する。

【症例】49歳，女性。主訴は動悸，右肩鈍痛。近医で 心電図異常を指摘され，当院受診時には心電図上前壁 梗塞を認めた。甲状腺機能六進症と頻脈が認められた ため, 抗甲状腺剤による治療を行った後, 冠動脈造影 （CAG）を施行した。CAGでLMCAに90\%狭窄が認められ， 右冠動脈から左冠動脈に側副血行が認められた。左室 造影上駆出率は $48 \%$ とやや低下していた。 nitroglycerinの静注を開始し，5 日後に手術を施行じた。

【手術】寒冷凝集抗体が陽性であったため，人丁心肺 は無血充填で体外循環を行うこととした。BSA $1.24 \mathrm{~cm}^{2}$, 術前Hb $12.4 \mathrm{~g} / \mathrm{dl}$, Ht $36.6 \%$ であった。胸骨正中切開 の後, 上行大動脈送血, 右房脱血で体外循環を行った。 主肺動脈にテープを通した後，大動脈を遮断し大動脈 基部より心筋保護液を注入し，大動脈基部を横切開し た。左冠動脈口を確認した後，大動脈切開を左冠動脈 口に向けてさらに延長した。左冠動脈口は直径 $1.5 \mathrm{~mm}$ のプローブがかろうじて通過する径であった。肺動脈 に通したテープを上外側に引きながら，LMCA前面の脂 肪組織を末梢側まで充分に剥離した後，大動脈から

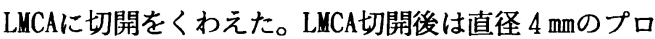
ーブが通過可能となった。あらかじめ採取した幅 $15 \mathrm{~mm}$ の自己心膜パッチを6-0 polypropylene系による連続 縫合で冠動脈切開部から大動脈切開部に縫着した。残 りの大動脈切開部は4-0 polypropylene系で連続縫合 した。冠動脈からの出血は少なかったため, 左房ベン 卜は必要なかった。大動脈基部より空気抜きを行い, 大動脈遮断を解除した。吻合部からの出血を認めず, 人工心肺からの離脱も容易であった。心停止時間 110 分, 人工心肺時間 160 分であった。ICU入室時の $\mathrm{Hb}$ $10.5 \mathrm{~g} / \mathrm{dl}$, Ht $33.0 \%$ \%゙り, ドレーンからの出血量 も少なかったため輸血を必要としなかった。循環動態 は, 少量のカテコラミン使用下で安定しており, 術翌 日に気管チューブを抜管した。術後造影は未施行であ るが，退院前に施行予定である。

【結語】LMCAのパッチ拡大術は, 適応を選んで施行す れば有用な治療法であると考えられる。 
E-64 上行大動脈瘤 - 大動脈弁輪搪張 $\cdot$ 大動脈 弁閉鎖不全を合併した先天性大動脈二尖弁に対する Wheat変法手術

社会保険紀南総合病院心臟血管外科

阪越信雄, 平中俊行, 古谷保博, 矢倉明彦, 前田 晃 【目的】大動脈弁輪拡張を伴う大動脈弁閉鎖不全に対 しては, Bentall手術を中心とする composite graft法 が広く行われているが，冠動脈口の処理等に関してい まだ問題が残されている。一方, Wheat手術をはじめと した独立置換法は，残存大動脈壁からの㿔発生に問題 があると指摘されてきたが, 最近この問題を解決した 新しい手術法(Wheat変法手術) が報告された。我々は 上行大動脈瘤・大動脈弁輪拡張・大動脈弁閉銷不全を 合併した先天性大動脈二尖弁に対しWheat変法手術を 施行し良好な結果を得たので，手術手技をビテオにて 供覧する。

【症例】59才男性。3 力月前より動悸, 胸部不快感が 出現。上行大動脈瘤 - 大動脈弁輪搪張 - 大動脈弁閉銷 不全 (3/4)を合併した先天性大動脈二尖弁と診断され, 手術目的にて当科紹介となった。

【手術】胸骨正中切開。大腿動脈送血，右房 1 本脱血 で体外㿟環を開始。上行大動脈瘤は腕頭動脈起始部に および最大径 $60 \mathrm{~mm}$ であった。大動脈遮断後，上行大動 脈を切開し順行性にGIK液を注入した。大動脈弁は前 尖後尖タイプの二尖弁であった。左／右冠動脈口と大 動脈弁輪との距離はそれぞれ $18 \mathrm{~mm} / 20 \mathrm{~mm}$ で，冠動脈口 の弁輪からの変位は少なく, Wheat変法手術が可能と判 断した。弁尖切除後に弁輪径を湘定し，27mmの

Medtronic-Hall弁をナレジッ付 2-0刹戊レ゙(15針) 逆マy 以下縫合で弁輪に縫着した。次に $30 \mathrm{~mm}$ 人工血管(woven Dacron）の近位側背側にコの字型の切れ込みを入れ， 3-0叔片ピ連続縫合で人工弁輪および左冠動脈口周囲 の大動脈壁に縫合。続いて人工血管近位側腹側にもコ の字型の切れ込みを入れ，人工弁輪および右冠動脈開 口部周囲の大動脈壁に縫合した。人工血管末梢側は, 横切断した後テロロクェルで補強した大動脈壁に3-0籼戊 レで連続吻合した。人工心肺時間 232 分, 大動脈遮断 時間 171分で手術を終えた。

【術後経過】術後血行動態は安定しており，虚血性の 心電図変化PCPK上昇はなかった。退院前に施行した 大動脈造影では，大動脈弁周囲逆流および吻合部動脈 瘤を認めなかった。

【結語】上行大動脈瘤・大動脈弁輪搪張・大動脈弁閉 鎖不全を合併した先天性大動脈二尖弁に対し, Wheat変 法手術を施行した。本法は人工血管近位側をコの字型 に切り込んだ上で人工弁輪に直接縫合するものであり, 冠動脈の再建が不要で, かつ遗残大動脈壁が最小限と なるという長所を持っている。冠動脈口の変位が大き くない症例においては選択されるべき術式であると考 えられる。
E一65 AAE、ARおよびTAA切迫破裂に対す 万手術

名古屋大学胸部外科

玉木修治, 伊藤敏明, 高木 靖, 市原利彦, 梶山 真 水野俊一, 田中 稔, 阿部稔雄

大動脈基部抬張症 $(\mathrm{AAE}) 、$ 、動脈弁閉鎖不全症 $(\mathrm{A}$ R)による心不全および下行大動脈瘤（TAA）の切迫破 裂を認めた症例に Bentall 手術、弓部大動脈置換術, 下行大動脈のElephant trunk設置術を行ったので供覧する。 【症例】 20 歳の男性。Marfan 症候群であり突然の前胸 部痛で発症した。弓部大動脈は正常であるがTAA壁 は血液の染み出しによると思われる肥厚を認め、両胸 腔には胸水の貯留を喼めた。またAAEがあり重篤な $\mathrm{AR}$ で心不全の状態にあり側開胸による下行大動脈人工 血管置換術は困難と判断した。

【手術】あらかじめ $23 \mathrm{~mm}$ の人弁と $26 \mathrm{~mm}$ の人工血管で valved conduit t作成、乙れに頸部動脈置換用3分枝と 冠灌流および体循環のための送血用分枝を側枝として 作成した。右腋窩動脈と右大腿動脈を露出して脳分離 および体外循環に備えた。胸骨正中切開の後、皮切を左 頸部に延長し頸部 3 分枝と弓部大動脈を露出した。右大 腿動脈送血、両大静脈脱血に上り体外循環を開始、上行 大動脈を遮断、逆行性心筋保護法による心停止下に大動 脈を縦切開した。ARは先天性病変によると考えられた。 また右冠動脈口は $2 つ$ 存在した。Bentall手術は通常の でとくvalved conduit を弁輪部汇縫着、冠動脈再建は Piehler法で施行したが右冠動脈口は2つとも slit状と なったのでCarrel patch法により再縫合した。ての時点 で逆行性心筋保護法を停止し送血用人工血管から巡行 性冠灌流を行った。虚血時間は111分であった。次い で右腋䈑、左総頸動脈送血による脳分離体外循環を開

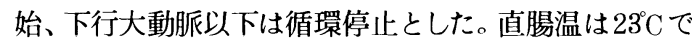
あった。約 $5 \mathrm{~cm}$ 内翻させた $22 \mathrm{~mm}$ 人工血管を T A A 内に挿 入、Elephant trunkとし中枢側を弓部大動脈内に縫着 した。内翻させた人工血管を引出し、valved conduit の末梢端と縫合した後、巡行性冠灌流路としていた送 血用人工血管を体循環の送血路とした。循環停止は 54 分であった。無名動脈、左総頸動脈を順次再建し脳分離 体外循環を停止した。脳分離時間は右側が74分、左側 が86分であった。左鎖骨下動脈を再建し充分復温した 後人工心肺から離脱した。人工心肺時間は 265 分であ った。術後 CTでは T A A 内に血栓形成を認め、現在術 後 5 ケ月で経過を観察している。

【まとめ】上行、下行大動脈病変に対し同時手術を必要 とする症例に対してElephant trunk法は有用である。

またvalved conduitにあらかじめ作成した送血用分枝 は心虚血時間の短縮、Elephant trunt設置後の体循環 送血路として有用であった。 
E-66 腹直筋有茎性胸骨翻転術、僧帽弁置換術, Cabrol手術を一期的に施行したMarfan症候群の 1 例 静岡赤十字病院心臓血管外科, 慶應義塾大学外科*

東 茂樹, 申 範圭, 二宮英樹, 川田光三*

漏斗胸を合併する開心術症例においては, 一期的手 術に対する手術適応，術式選択・術後出血など，なお， 幾つかの問題が残されている。今回, 和田分類 3 度の 漏斗胸, Seller分類度の僧帽弁閉鎖不全, および Seller分類 II 度の大動脈弁閉鎖不全を伴うannuloaortic ectasiaを合併するMarfan症候群の23歳女性に 対し, 腹直筋有茎性胸骨翻転術, 僧帽弁置換術, Cabrol手術を一期的に施行したので，その手術手技を ビデオで供覧する。

【手術】胸部正中皮膚切開を加え, 漏斗胸の傾斜変換 線の外側まで皮下組織・大胸筋を剥離した。左側の肋 骨弓から始め, 肋骨を傾斜变換線上で離断。肋間動脈 を結紮しながら第 3 肋骨まで達し，第 2 肋間の高さで 胸骨を横断，両側内胸動脈を結紮切断した。右側も同 様に処理し，胸骨・肋骨複合体を腹直筋を付けて下方 に反転した。第 2 肋間以上の胸骨は絴切開した。FAに $18 \mathrm{Fr}$, SVC に24Fr, IVC に30Frのカニューレを挿入し 体外循懪を開始した。上行大動脈を遮断後, 大動脈瘤 を切開し, 冠動脈口へ選択的に心筋保護液を注入した。 右房切開, 心房中隔切開, 左房上壁切開にて僧帽弁に 到達するcombined superior-transseptal approachを 用いたが，僧帽弁に対する視野は非常に良好であった。 SJM 31M にて弁置換を行なった後, 左房上壁, 心房中 隔を4-0 サージリン糸にて連続縫合閉鎖した。ついで， 大動脈弁を切除後, 径8 $\mathrm{mm}$ の Gelseal を左冠動脈口へ 4-0 サージリン糸を用いて連続縫合し, さらにプレジ エット付4-0 タイクロン糸にて，4 ケ所補強を加えた。 この人工血管にFoley カテーテルを挿入し, 心筋保護 液を注入し, 漏れの有無を確認した。次に径 $24 \mathrm{~mm}$ Gelseal にSJM21Aを䊚着したcomposite graft を2-0 ネスポーレン糸を用い, マットレス䋖合にて大動脈弁 輪に絴着した。右冠動脈口と径8 $8 \mathrm{~mm}$ Gelseal との吻合 も左の場合と同様に行なった後, 両人工血管を吻合し た。上行大動脈は切断し, 外側にフェルトを当てて補 強し, 人工血管と吻合した。人工血管より terminal warm blood cardioplegia を注入し大動脈遮断を解除 した。胸骨・肋骨複合体をトリミングした後、これを 180度翻転し胸壁の形成を行なった。胸骨上端は重曽 するようワイヤーで固定し, 肋骨は1-0 Nylon 糸にて 縫合した。大動脈遮断時間 2 時間 40 分, 体外循環時間 4 時間 8 分, 手術時間 13 時間 30 分, 出血量は $4350 \mathrm{~m} 1$ で あった。

本例では手術野の確保の上で, 胸骨翻転術, combined superior-transseptal approach が有用であった。
$E-67$

左冠動脈主幹部限局性病変に対する冠動

脈再建術

松戸市立病院心戥血管外科

渡辺寞、香西襄、芝入正雄、宇津見和郎、永瀨裕三、 大橋幸雄、茂木健司

左冠動脈主幹部 (LMT) 病変は絶対的外科治療の 適応であり、完全血行再建術および適切な心筋保護手 段を用い手術成績の向上が報告されている。その中で L M T 限局性病変（閉塞性病変がL M T 限局され、 L A D seg. 6. とC X seg. 11. の交通性が保たれてい る）の手術手技として

（1）動脈グラフトに因る夫々 L A D とC Xへのバイ パス術

（2） T E A、patch repair法、punch-out 法の直達 手術

がおこなわれている。（1）の場合、グラフトの初期血 流量の不足に因る L O S の発生やL M T 狭窄度が50 75\%の場合、動脈グラフトのstring現象の発生が報告 されている。（2）の手術成績についても未だ一定せず 、簡便かつ普逼的な手術手技には未だ至っていない。

我々は L M T限局性病変に対しては、SVGを用い てLMTseg. 5.〜L A D seg. 6.にわたる部位に末梢㑡 吻合を行い、transverse sinusを通して上行大動脈後 壁に中枢側吻合を行うC A B Gを行っているのでこの 手術手技につき供覧したい。

【症例】56才男性、診断は不安定狭心症、冠動脈造影 にてLMT seg. 5. 末梢部に $99 \%$ 狭窄、L A Dは造影さ れず、ただseg.6.にてto and fro像がみられた。右冠 動脈造影にて L A D とCXが逆行性に造影された。左 主幹部限局性病変としてC A B Gを行った。

【手術手技】正中切開にて開胸、肺動脈主幹部にもテ 一ブを回しておく。体外偱㻴、心停止下にて、肺動脈 後面を走る $\mathrm{L} M \mathrm{MT} \sim \mathrm{L} A \mathrm{D}$ を触知確認し、心外膜下脂 肪組䅧を分けると同部か露出できる。この際肺動脈に 回したテープを右側に引っ張ると術視野が良好となる。 L A D中枢部を切開（LMT病変直末梢）、7-0 proleneにてS V Gを吻合. 大動脈逝断のまま、SVGを transverse sinus を通して大動脈右側に引出す。大 動脈造断鉗子と大動脈基部軟部組織を肥持した鉗子に て大動脈を左側にねじるようにして大動脈後面を術視 野に出し、同壁をパンチアウトし、S V Gの走行、ね じれ、長さの調節を確認して、5-0 prolene にて吻合 し、CA B G 完成させた。術後造影にてSVGより L $\mathrm{AD}$ と C X全域が灌流される像が得られた。

【結語】 L M T限局性病変に対してLMT〜L A D 部 位から transverse sinus を通して大動脈後壁への $\mathrm{S}$ V Gによるバイパス術は、グラフト流量が左冠動脈全 域を供給するに充分であり、短かく、かつ直線的走行 のグラフトは、長期開存性に有利と考える。 
E-68 バイポーラ・レーザーメスで剥離した内 胸動脈と右胃大網動脈を用いた冠動脈バイパス術 東京女子医大心研循環器外科

広田 潤, 小柳俊哉, 高沢有史, 八木葉子, 西田 博, 中野清治, 遠藤真弘, 小柳 仁

【目的】動脈グラフトの剥離側枝処理法には, 用手結 禁法や電気メス，血管クリップを用いた方法がある。 いずれも分枝動脈の止血, 切離とグラフト本幹への影 響を常に留意しなければならない䋞細な手技である。 一方, レーザー光は波長により一定範囲の凝固, 止血 能力と, 切開能力を合わせ持つ。今回, Nd-YAGLザー (CL-X, SLTジャパン社製) を光源とするバイポ 一ラ型・レーザーメスで, 左内胸動脈 ( L ITA) と右胃 大網動脈( GEA) を採取し, 手術手技上の有効性を検討 した。レーザーメスによる動脈グラフトの剥離手技と, 採取したグラフトによる冠動脈バイパス術を供覧する。 【症例】64歳, 男性。7 年前よりの労作性狭心症を認 め, 内科治療を受けていたが, 不安定狭心症となった ため手術目的にて当科紹介。術前の冠動脈造影所見で は右冠動脈に 1 1: $50 \%$, \#2:75\%の狭窄病変, 左冠 動脈に\#6:75\%，\#7:75\%, \#12:75\% の狭窄病変 を認めた。左室造影では seg. 2, 4, 7 亿軽度の壁運動 低下を認めた。

【手術】胸骨正中切開を行い, 初めにLITAを,続いて GEAを剥離し, 同時に左下腿から大伏在静脈 (SVG) を採取した。レーザーメスの出力条件は $15 １ 8 \mathrm{~W}$ の 連続照射とし, 切離目的部位をハンドピース先端では さみ, 血管及び組織が蒸散, 切離されるまで数秒間レ 一ザーを照射した。組織の反応により漸次, 出力を調 整した。LITAの剥離は skel toni zationで行い, 肋間 動脈および結合組織の切離にバイポーラ・レーザーメ スを用いた。LITA 本幹から数m離してはさみ, レー ザーを照射すると, 約 $1 \mathrm{~mm} の$ 熱凝固と共に側枝は切離 され，止血は確実であった。GEAは大網組織と動静脈

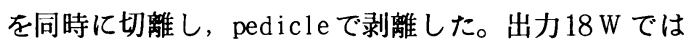
切開が熱凝固を上回り, 直径 $1 \mathrm{~mm}$ 以上の動静脈では止

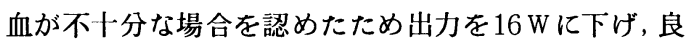
好な止血効果を得た。先端からのポイントレーザー光 あ止血に適宣利用し, 確実かつ迅速に剥離し得た。特 に胃大彎側の剥離では細かい操作がスピーディーに行 え，有用であった。CABGはLITAを\#OMへ，GEAを LAD \#7へin situで吻合し, SVGを\#3に吻合した。 人工心肺離脱は特に問題を認めず, 心肺離脱後のレー ザーメス使用部の止血に問題を認めなかった。

【結語】バイポーラ・レーザーメスによる動脈グラフ トの剥離は, 切離, 止血が確実に行え, 剥離時間の短 縮か得られると考えられた。
E一69体外循環を用いない心拍動下のACバィハ ス術

爱知県立尾張病院心膤血管外科

碓水章彦、吉田勝彦、日比道昭、川村光生

【目的】体外循環は人工肺、血液ホンプの進歩により 安全な補助手段となってきたが、血液損傷、血液希积、 全身冷却など開心術の手術侵襲の大きな要系となって いる。また、体外循環に起因する塞栓症は重篤な合併 症であり、予期できない偶発症として手術死亡の避け られない原因となっている。われわれは手術侵襲を軽 減する目的で L A D 領域およびR C A \#2、\#3に対 し体外循環を用いず、心拍動下にA C バィパス術を行 う術式を試みている。本演題ではバイパス術における われわれの工夫を紹介するととるに、手術成績を報告 する。

【症例】46 から76才の男性 4 例、女性 1 例に体外 循環を用いずにACバイパスを行った。 L I T A - L A D バイパスを 3 例に、 R I T A - R C A バイパスを 1 例に、 $\mathrm{S} V \mathrm{G}-\mathrm{R}$ C A バイパスを1例に施行した。 2 例は P T C A 再狭窄例、1 例は再手術例であった。 吻合中の末梢側灌流は 3 例に行い、バイパス吻合時間 は7-17 分、平均 $13 \pm 3$ 分、吻合中の心虚血時間 は 5-15 分、平均 $8 \pm 4$ 分であった。 3 例を無輸血 で行い、手術時間は 4 時間 25 分士 38 分であった。 術後グラフト造影では全グラフトの開存が確認できた。 【手術術式】胸骨正中切開で開胸し、LI T A C U S A を用い㔀離した。心腈をスポンジを用いL A D が 露出するように脱転し、L A D は C S A を用い吻合 部上下約 $2 \mathrm{c} \mathrm{m}$ を剝離し、上下をエラスチック $\mathrm{P}$ を用 い二重に吊り上げ出血をコントロールするととるに、 L A D の吊り上げ固定を行った。 L A D 切開は約 $5 \mathrm{~m}$ $\mathrm{m}$ と長めに行い、E C G C S T 変化がみられる場合に は $5 \mathrm{~F}$ のパーフュジョンカテーテルを末梢側冠動脈に 留置し、大腿動脈に捙入した動脈カテーテルと連結し 末梢側心筋の灌流を行った。5Fカテーテルで20一 $30 \mathrm{~m} \mathrm{1} /$ 分の流量が得られ、E C G 变化は全例消失 した。吻合は7ー0ポリプロピレン糸を用い、L I T A を 把持した状態でヒ一ル側を連続繾合した後、系を変え トゥ側の吻合を連続で行った。パーフュジョンカテー テル抜去し、L I T A を吻合部に接合させ、繾合の残 りを追加し吻合を終了した。 R C A ののバイパスす同 様の方法で行った。S V G の中枢側吻合は末梢側吻合 を行う前にサイドクランプを上行大動脈基部にかけ、 6ー0ポリプロピレン系連続縫合により行った。

【総括】 L A D 領域、R C A \#2、\#3へのバイパス は体外循環を用いず心拍動下に施行可能であった。こ の術式によりACバイパス術の手術侵襲の軽減および 塞栓症合併率の低下が期待できた。 
E一70人工心肺を用いない心拍動下冠状動脈バ イパス術

聖マリア病院胸部心臟血管外科

田代 忠, 藤堂景茂, 春田泰伸, 安永 弘, 立川 裕 冠状動脈バイパス術（以下 CABG）は人工心肺を使 用し心停止下に行なうととが一般的である。最近、人 工心肺及び心停止を用いずに心拍動下にCABGを行な う方法が報告されており、我々も15例行ない良好な結 果を得た。今回、そのうちの 1 例の手術手技を供覧す る。また人工心肺を用いない心拍動下CABGの有用性 につき検討し報告する。

[対象]最近4年6力月に行なったCABG 症例 200例のう ち人工心肺を使用しない心拍動下 $C A B G を$ 行なった 15 例は、年齢47-82歳、平均65歳であり、70歳以上の高 齢者を 7 例ふくんでいた。左心機能低下例（LVEF： 13，28\%）を2 例に、腎不全（透析例）を1例に合併 した。大動脈瘤を 2 例（胸部、腹部各 1 例 ; 胸部また は、腹部大動脈人工血管置換術同時施工）に、頸動脈 狭窄 (carotid endarterectomy同時施工) を 1例に合併 した。

[手術方法]胸骨正中切開の後、内胸動脈を採取した。 心膜を切開し心臓を露出した。へパリンは $1 \mathrm{mg} / \mathrm{kg}$ を静 注した。心後面に柄付きガーゼを置き冠状動脈 (LAD または RCA) が前面にくるように心臟を挙上した。血 圧、心電図に変化のないととを確認したのち、冠状動 脈を剥離した。冠状動脈の吻合予定部の中枢側と末梢 側に3-0ネスポーレンにてテーピングを行ない冠状動 脈を遮断した、冠動脈切開ののち、ITAまたはSVG を連続縫合にて吻合したのち冠動脈遮断を解除した。

[結果] 1例あたり 1-2力所、1.6力所のバイパスを行 なった、ITAは全例で使用した。吻合部位は、LAD 15 力所、RCA 8 力所であり、RCAの endarterectomy を 2 例に行なった。 1 力所の吻合に必要とした冠状動 脈遮断時間は 7-14分平均 10.3 分であった。早期死亡、 心筋梗塞、術後 IABPは $0 \%$ であった。

[結論]自験例15例の経験より、人工心肺を用いない 心拍動下 CABGは、体外循環、心停止の侵襲を全く受 けるととなくCABGが可能であり、LAD, RCAに対す る ITA，SVGを用いたCABG、RCAのendarterectomy が可能であった。また、ITAのみを用いれば aortic no-touch technique む可能であった。人工心肺を用い ない心拍動下CABGは、CABGの安全性を更に向上さ せ、今後重症例を含めてCABGの適応を拡大する有用 な方法であると考えられた。
Eー71 Non-touch aortic techniqueによる 冠動脈バイパス手術

岡谷塩嶺病院 心臟血管外科、日大第 2 外科* 大平政人、奥村晴彦、山本知則、奈良田光男、 秋山謙次 ${ }^{*}$ 、瀬在幸安 ${ }^{*}$

冠動脈バイパス術 (CABG)の安定した手術成績が得ら れるにつれ、より重症例にチャレンジする機会が増加 している。とくに大動脈に動脈硬化が広範囲におよび 石灰化をきたす症例では補助手段、手術手技に種々の 工夫を行うことが手術成功のポイントである。

今回我々はかかる症例にVF+超低体温法を用いてNontouch aortic techniqueによるCABGを行ったので報 告する。

[症例]69才、男性、職業は農業。S 53年 1 月より 労作時の胸痛あり、61年某病院にてCAGを行い、内科 的にて経過観察していた。しかし、平成 3 年 4 月より 胸痛が頻回となったため10月 7 日当院にて再度 CAGを 行った。LVGではEF 67\%, seg.6で完全閉塞、seg.13に 90\%狭窄があり、LAD末梢はRCAよりの側副血行にて 造影された。胸部 CTでは上行大動脈前面より右側面 腕頭動脈起始部にかけ広範囲の石灰化がみられた。以 上より石灰化大動脈を合併した 2 枝病変の不安定狭心 症と診断し、12月 4 日に手術を行った。

[手術術式および手術所見]全身麻酔下に右鼠脛部 を露出し大腿動静脈を確保した。次いで胸骨正中切開 を行いLITAの剥離を行った。free flowは38ml と良 好で使用可能と判断した。上行大動脈を触診すると石 灰化は術前の診断どおりで、大動脈遮断は危険と判断 した。Cxの中枢側吻合予定の腕頭動脈涪分遮断鉗子 をかけると浅側頭動脈の拍動が弱くなったため超低体 温+VFとしてCABGを行うことにした。右大腿動脈より $24 \mathrm{Fr}$ 、大腿静脈より $30 \mathrm{Fr}$, th in wall カニューレを右房ま で挿入し、人工心肺をスタートした。さらに左房ベント を挿入し、VFになった時点で充分左室を減圧しつつ seg 14を切開し、SVGと7-0 プロレンで 連続縫合を行 ったっつぎに seg 8 を切開し、8-0 プロレンにて LITAと 吻合した。最後に腕頭動脈に部分遮断鉗子をかけて 6-0 プロレンにて Cx の中枢側吻合を行いCABGを 終 えた。VF時間は68分、人工心肺時間は 222 分を要した が、加温中に自然拍動が再開した。人工心肺より離脱 時LOSとなり IABPを必要としたが ICU 帰室後は血行 動態は安定した。術後胸痛は全く消失し、1ケ月後のグラ フト造影であ二本のバイパスとも良好な開存を示し、EF も $81 \%$ へと改善した。

[考察]石灰化大動脈を合併したCABG を行う際、 補助手段に工夫を行いNon-touch aortic technique にて手術を行うことが重要である。 


\section{$E$-72 左開胸による冠動脈再手術}

山口大学第一外科

盇井英敏, 岡田治彦, 西田一也, 古永晃彦, 浜野公一 藤村嘉彦, 江里健輔

近年冠動脈手術の増加とともに再手術症例も增加し てきた。再手術の際どのような到達法が最適であるか は画一的でない。今回左開胸によりVf下で左鎖骨下動 脈ー14PLバイパス症例を供覧する。

症例は69歳男性、1982年LAD、14PLに大伏在静脈を 用い冠動脈バイパスが施行された。1991年3月狭心発 作を生じるようになり、さらに10月にunstable angina となった。冠動脈造影によりLADのgraftは開存してい たが、4PD：99\%、Cx：75\%、14PL：90\%の狭窄を認 めた。心筋シンチ等の精査により責任病変は14PLの graft閉塞と診断し、同部に再バイパス術を行うこと とした。

手術は左第 5 肋骨床開胸を行い、送脱血は大腿動静 脈より行い、肺動脈、左房ベントを併用して人工心肺 を使用した。さらにIABPも使用した。16〜20 $\mathrm{C}$ の超低 体温、Vf下でLITAを用い14PLに吻合した。しかし十分 なflowが得られないため、急遽大伏在静脈を用い左鎖 骨下動脈ー14PLの吻合を行った。術後経過は良好であ つた。

本到達法の利点は前回手術後開存しているLADへの graft損賃の危惧もなく、かつ必要以上の剥離を要し ないことである。従ってLAD、Cx領域の再手術を安全 に行うのに適した到達法であると思われる。
E-73 心筋梗塞後心室馏に対する Ventricular Endoaneurysmorrhaphy

山梨県立中央病院心臟血管外科

鈴木章司，土屋幸治，大塚吾郎，上杉英之，飯田良直 心筋梗塞後心室瘤に対しては, 従来心室瘤を切除しフ ェルト片を用いたlong linear sutureで閉鎖する方 法（linear closure）が標準術式となってきた。しか し広範な心室瘤を有する症例では, 左室形態の変形や残 存左室容積の減少が生じることから, 久損部を purse string sutureやpatchを用いて閉鎖する方法 (circular closure) を推奨する報告もみられる. 近年, Cooley 等 は心室瘤に対する新しい術式として intracavitary repair である “ventricular endoaneurysmorrhaphy”を 行いその有用性について報告しているが, 今回我々も本 法を用いて良好な結果を得た症例を経験したので供覧 する.

【症例】 79 歳, 男性. 1992 年 6 月 11 日, 前胸部痛で 発症. 前壁中隔の心筋梗塞の診断で当院内科にて保存的 に治療された７月15日の心㖑カテーテル検查にて，一 部中隔にかかる大きな心室瘤を指摘された。冠状動脈造 影では，\# $199 \%$ ，６９９％，１1 50\%の狭窄病 変があり, LVEF $23.4 \%$, LVEDP $20 \mathrm{mmHg}$ であった. 前下行枝が recanalizationしており, 近位の中隔枝の 領域ではwall motionが良好なため, 心室瘤の repair と右冠動脈及び前下行枝への 2 枝バイパス手術の適応と して, 1992 年 9 月 1 日, 手術を施行した.

【手術及び経過】胸骨正中切開を行い，大伏在静脈グ ラフトを採取した. 人工心肺は上行大動脈送血, 右心房 脱血, 肺動脈ベントとした，心室細動下に左室前壁の心 室瘤に繸切開を加え, 左室内腔を観察し線維化した心能 の範囲を確認した. 大動脈遮断の後, 心筋保護液を注入 し, 右冠動脈及び前下行枝へのバイパスの遠位側吻合を 行なった. 次に心膜で裹打ちしたテフロンフェルトパッ チを，約 $3 \times 5 \mathrm{~cm}$ の長円形にtrimmingし，心室瘤の 境界に沿って 3-0 Proleneの連続繾合で左室内腔に繾 着した，心室溜壁の切開部はそのまま連続繾合にて閉鎖 した. 大動脈遮断解除後, バイパスの近位側吻合を行な った. 人工心肺からの離脱は容易でIABPは不要であっ た. 手術時間 5 時間 5 分, 人工心肺時間 2 時間 17 分, 大 動脈遮断時間 59 分であった。

術後の経過は極めて良好で, 第 1 病日に呼吸器を離脱, ドーパミンは最大 $5 \gamma$ で, 第 4 病日に離脱可能であった. その後 symptom freeの状態で退院に至った.

【結語】ventricular endoaneurysmorrhaphyは, 広範な心室瘤や中隔瘤を合併した症例においても，左室 の形態や残存左室容積を保つことが可能で, 血行動態の 改善に有用であった。 また，心室切開の繾合部からの出 血の危険性が少なく、フェルト片を用いないため前下行 枝へのバイパスも容易であった. さらに心室中隔穿孔合 併例等への応用も可能と考えられた. 


\section{$E-74$ 梗塞後仮性左室瘤に対する左室再建術}

岡谷塩嶺病院心臟血管外科、日本大学第 2 外科*

大平政人、山本知則、奥村晴彦、奈良田光男、

秋山謙次 $*$ 、瀬在幸安 ${ }^{*}$

心筋梗塞後に生じる仮性左室瘤は極めて稀な合併症 であるが、二次破裂を生じやすく予後不良な疾患であ る。従って救命の為には早期の外科治療が必要である。

手術方法は仮性左室瘤を含めた瘤切除術が一般的で ある。これに対し、今回我々はより生理的な術式とし て左室再建術を行い良好な結果を得たので報告する。

[症例 ]57才、男性。主訴は労作時の背部痛。1 年 前にAMIの既往歴あり。退院時に左室瘤の診断を受り ており、以後外来にて経過を見ていたが時折、背部痛 が出現し、平成 4 年 3 月に精査目的にて再入院となっ た。電図ではI, $\mathrm{aV}_{\mathrm{L}}$ にQ波、 $V_{1} \sim V_{5}$ にST上昇を伴う $\mathrm{Q}$ 波がみられ、1 年後の胸部 $\mathrm{X}$ 線像で左第 4 弓が僅か に突出した所見がえられた。冠動脈造影では seg. 6 起 始部で完全閉塞、s eg. 13末梢に75\%狭窄がみられ、左 室造影で前壁から心尖部にかけて広範囲に dyskinesis が見られた。さらにその一部が半球状に突出した淡い 陰影を認め、機能心筋収縮率は $48 \%$ 、瘤周径比は $45 \%$ であった。

以上より本例は前側壁の真性左室瘤に合併した仮性 左室瘤と診断し6月17日に手術を行った。

[手術所見及び手術術式]上行大動脈送血、右房 1 本脱血とし、軽度低体温、心室細動下に手術を行った。 左房ベントにて左室を減压しながら最む癒着の強い左 室前壁から心尖部、側壁にかけて剥離をすすめた。仮 性左室瘤は $4.7 X 3.6 \mathrm{~cm}$ の大きさで内部は血栓にて充満 しており真性左室瘤 $(10 X 8.7 \mathrm{~cm}$ )の一部が膨隆した形態 であった。次に仮性左室溜をふくめて 6 X $4 \mathrm{~cm}$ 切除し左 室再建にうつった。まず心内膜側に 3-0 プロレンにて タバコ縫合を行い、瘤徍を $2 / 3$ 程度に縫縮したうえで自 己心膜で裏打ちしたGore-tex パッチ(厚さ $0.6 \mathrm{~mm}$ ) を 3-0 プロレン連続縫合により左室の再建を行った。心室 細動時間は 83 分、人工心肺時間は 149 分で離脱は容易 であった。

術後経過は極めて順調で術前の症状は消失した。1 ケ月後の冠動脈造影でも LVEF は術前30\%より術後54 $\%$ へ、LVEDP は $19 \mathrm{~mm} \mathrm{Hg}$ より $5 \mathrm{~mm} \mathrm{Hg}$ へと改善した。 LVEDV I は術前 $103 \mathrm{ml} / \mathrm{m}^{2}$ 、術後 $96 \mathrm{ml} / \mathrm{m}^{2}$ と殆ど変化な く左室容量は良好に保つことができた。

また術後病理学的検索では壁は菲薄化し、仮性左室 瘤の部分には心筋組織は全く認められなかった。

[結語]今回、心筋梗塞後に生じた仮性左室瘤に対 し自己心膜で裏打ちしたGor e-tex の二重パッチによ る左室再建術を行った。術後左室造影からもほぼ満足 できる術式であり、今後さらに通常の真性左室瘤にも 応用してゆく方針である。 